\title{
PEMBERDAYAAN MASYARAKAT MELALUI REPOSISI MASYARAKAT DALAM PROSES PERUMUSAN PENGANGGARAN DI TINGKAT DESA (STUDI KASUS DI DESA KOTAYASA DAN BANJARSARI WETAN, KECAMATAN SUMBANG, KABUPATEN BANYUMAS)
}

\author{
Sukarso $^{1}$, Swastha Dharma ${ }^{2}$, Niken Paramarti Dasuki ${ }^{3}$ \\ ${ }^{1}$ Program Studi Administrasi Negara Universitas Jendral Sudirman \\ ${ }^{2}$ Program Studi Administrasi Negara Universitas Jendral Sudirman \\ ${ }^{3}$ Program Studi Sosiologi Universitas Jendral Sudirman \\ sukarso_upb@yahoo.co.id
}

\begin{abstract}
Abstrak
Selama ini, perumusan kebijakan hampir selalu dilakukan oleh pihak elit, bahkan secara formal elit mempunyai otoritas itu sementara masyarakat tidak. Mekanisme ini dibakukan dalam bentuk model-model perumusan, seperti institusional, rasional bahkan model incremental, dan terutama model elit-massa. Posisi masyarakat secara langsung pada umumnya relatif lemah atau bahkan nyaris tidak ada. Inisiasi untuk melibatkan lebih banyak peran masyarakat dalam perumusan kebijakan sudah banyak dilakukan seperti dalam model deliberatif dan partisipatif, namun tetap saja keterliabtan masyarakat mesih menjadi obyek, bukan subyek perumusan kebijakan. Model perumusan kebijakan yang elitis seperti ini, terutama di Indonesia, terjadi baik tingkat nasional, provinsi, maupun kabupaten/kota, yang terakhir di tingkat desa pun demikian. Dari fakta tersebut, menarik untuk mengetahui potensi atau prospek masyarakat, terutama di tingkat desa, menjadi subyek dari perumusan kebijakan di tingkat desa. Kajian ini menggunakan pendekatan experimental dengan perlakuan peningkatan pemahaman dan kesadaran tentang perumusan kebijakan penganggaran atau pemberdayaan dalam aspek hukum, administratif, dan sosio-psikologis. Kajian ini memfokuskan pada proses perumusan anggaran pendapatan dan belanja desa di dua desa di Kecamatan Sumbang, Kabupaten Banyumas. Metode pengumpulan data menggunakan diskusi kelompok terfokus dan wawancara mendalam dengan informan yang dipilih secara purposif dan metode angket untuk responden yang terpilih secara aksidental, adapun analisis data menggunakan interaktif. Hasil kajian menunjukkan potensi dan prospek yang sangat tinggi dari masyarakat untuk menjadi bagian penting dan subyek dari proses perumusan kebijakan penganggaran tersebut.
\end{abstract}

Kata kunci: perumusan kebijakan, pemberdayaan, hukum, administratif, sosio-psikologis.

\section{Abstract}

So far, policy formulation almost carried out by the elite, even formally the elite has the authority while the community does not. This mechanism conceptualized in the form of formulation models, such as institutional, rational and even incremental models, and especially the elite-mass model. The position of the community directly is generally relatively weak or even almost non-existent. Initiation to involve more community roles in policy formulation has carried out as much as in deliberative and participatory models, but still, the involvement of the community becomes an object, not the subject of policy formulation. This elitist model of policy formulation, especially in Indonesia, occurs both at the national, provincial and district/city levels, the latter at the village level. By these facts, it is interesting to know the potential or prospects of the community, especially at the village level, to be the subject of policy formulation at the village level. This study uses an experimental approach with the treatment of enhancing their understanding and awareness about the formulation of budgeting policies or empowerment in legal, administrative and socio-psychological aspects. This study focuses on the process of formulating village income and expenditure budgets in two villages in Sumbang District, Banyumas Regency. Methods of collecting data using focus group discussions and indepth interviews with informants selected purposively and questionnaire methods for respondents who chosen accidentally, while analyzing data using interactive. The results of the study show the very high 
potential and prospects of the community to become an important part and subject to the process of the budgeting policy formulation.

Key words: policy formulation, empowerment, legal, administrative, socio-psychological

\section{A. PENDAHULUAN}

Penguatan posisi Pemerintahan

Desa di Indonesia secara signifikan dimulai dari ditetapkannya UU No. 6 Tahun 2014 pada tanggal .... Tahun 2014. Pada tahun yang sama, 2014, dirumuskan pula aturan-aturan pelaksanaannya dari mulai Peraturan Pemerintah (PP No. 43 Tahun 2014) sampai pada Peraturan Menteri Dalam Negeri (terutama Permendageri No. 113 Tahun 2014 tentang Pengelolaan Keuangan Desa). Produk kebijakan tersebut menunjuk pada dua hal, pertama kesungguhan pemerintah Indonesia dalam melaksanakan Undang-Undang tersebut, dan kedua, perubahan signifikan hak dan kewajiban Pemerintahan Desa dalam pengelolaan anggaran desanya. Kesungguhan Pemerintah Indonesia dapat diketahui dari cepatnya dirumuskan atura-aturan pelaksanaannya, dan perubahan signifikan nampak dari menguatnya penganggaran desa, baik dari besarnya dana yang dikelola maupun dari besarnya hak dan kewajiban yang dimiliki desa.

Dari fakta tersebut, mulai tahun itu juga Pemerintahan Desa mau tidak mau harus "menyesuaikan" dengan tuntutan kinerja yang ada. Tuntutan kinerja dalam konteks penganggaran berarti kemampuan atau keberdayaan Pemerintahan Desa dalam merumuskan anggaran tahunannya. Selama ini, sampai tahun 2014, pemerintah desa merumuskan anggaran pendapatan dan belanja desa hanya sebatas formalitas karena besaran dana yang relatif terbatas. Akan tetapi perumusan tersebut menjadi krusial ketika anggaran di tingkat desa menjadi relatif sangat besar dengan alokasi dana langsung (Dana Desa) dari Anggaran Pendapatan dan Belanja Negara (APBN), termasuk dana transfer lain dari tingakt Provinsi dan Kabupaten.

Krusial karena dengan alokasi dana dari APBN maka pemerintah desa harus tunduk pada berbagai aturan dari Kementerian Keuangan Republik Indonesia (misalnya, Peraturan Menteri Keuangan Republik Indonesia No. 49 Tahun 2016 tentang Tata Cara Pengelolaan, Penyaluran, Penggunaan, Pemantauan dan Evaluasi Dana Desa). Pada saat yang sama, pemerintah desa belum terbiasa merumuskan Anggaran Pendapatan dan Belanja Desa (APBDes) dengan mekanisme formal yang ketat sebagaimana diatur oleh berbagai aturan yang ada. Hal ini dapat diketahui dari berbagai kasus salah kelola atau penyimpangan dalam pengelolaan dana desa di Indonesia dalam beberapa tahun terakhir. Indonesia Corruption Watch (ICW) mencatat ada 181 kasus korupsi Dana Desa sampai dengan Nopember 2018. Hampir semua kasus tersebut dilakukan oleh Kepala Desa dan atau Perangkatnya. (https://nasional.kompas. com/read/2018/11/21/19000481/icwada-181-kasus-korupsi-dana-desarugikan-negara-rp-406-miliar, dikutip tanggal 23 Januari 2019).

Dari fenomena tersebut, dalam studi kasus di lima desa di Kebupaten Banyumas teridentifikasi bahwa peran masyarakat dalam perumusan APBDes sangat rendah (Sukarso, et.al., 2017). Masyarakat cenderung apatis dalam 
proses perumusan APBDes sebagaimana berjalan selama ini antara lain karena merasa bahwa perumusan APBDes bukan hak dan kewajiban masyarakat akan tetapi milik kepala desa dan perangkatnya. Urusan perumusan APBDes selama ini, de jure dan de facto, memang elitis atau hanya ada di sekitar elite desa, terutama pemerintahan desa dan kecamatan dengan kewenangan evaluasi draft APBDes-nya. Berbagai kajian tentang perencanaan partisipatif selama ini menunjukkan rendahnnya partisipasi masyarakat dalam berbagai aspek dan determinan (misalnya, Priskilia, 2015).

(http://administrasipublik.studentjourna l.ub.ac.id/index.php/jap/article/view/96 9) ; ... ).

Dengan demikian, dapat disimpulkan bahwa keterlibatan atau partisipasi masyarakat dalam perencanaan masih relatif rendah. Sementara itu, pengelolaan keuangan desa dalam beberapa waktu terakhir banyak ditulis tentang pertanggungjawaban pengeloaan dan juga perencanaan pembangunan yang lebih dikenal dengan musyawah rencana pembangunan masyarakat desa (Musrenbangdes), namun masih jarang yang memfokuskan pada bagaimana perumusan anggaran dan pendapatan desa. Oleh karena itu, dari uraian di muka, menarik untuk dikaji bagaimana model pemberdayaan masyarakat yang paling tepat dalam pengelolaan keuangan desa, terutama dalam proses perumusan anggaran pendapatan dan belanja desa. Isu model perumusan anggaran pendapatan dan belanja desa yang paling tepat untuk masyarakat desa tersebut berasumsi bahwa pemerintahan dan masyarakat desa harus diberi kesempatan untuk belajar mengelola sesuai dengan tuntutan formal pengeloaan keuangan negara di Indonesia. (Sukarso, et al. 2018).

Dari permasalahan penelitian dapat dikaji beberapa konsep yang relevan, yaitu Participation, Empowerment, street- level bureaucracy, deliberation, dan budgeting. Konsep-konsep ini menjelaskan sisi yang berbeda dari perumusan anggaran pendapatan dan belanja desa.

Participation atau partisipasi pada dasarnya adalah keterlibatan masyarakat, langsung atau tidak langsung aktif atau tidak aktif, dalam proses pembangunan atau pemerintahan. pada umumnya. Tokoh yang relatif menonjol dalam mengupas konsep partisipasi adalah Arnstein (1969) dengan ladder of citizen participation-nya. Partisipasi masyarakat dapat dibedakan dalam delapan tingkatan, mulai dari yang paling rendah, manipulation, therapy, informing, consultation, placation, partnership, delegation, sampai citizen control, yang paling tinggi. Partisipasi dalam konteks perumusan APBDes menunjuk pada tingkatan partisipasi citizen control di mana masyarakat hampir sepenuhnya dapat mengendalikan proses kebijakan yang ada. "People are simply demanding that degree of power (or control) which guarantees that participants or residents can govern a program or an institution, be in full charge of policy and managerial aspects, and be able to negotiate the conditions under which "outsiders" may change them." (Arnstein, 1969: p. 223).

Penelitian tentang partisipasi masyarakat dalam penganggaran sudah banyak dilakukan pada tingkatan pemerintahan lokal (antara lain Kim dan Schachter,2014; Lorsuwannarat, 2016; Liao dan Zhang, 2011) yang berusaha 
mengkaji faktor-faktor yang menentukan partisipasi masyarakat dalam penganggaran, namun kajian untuk penganggaran tingkat desa masih jarang dilakukan.

Empowerment menunjuk pada proses transfer kekuasaan atau power dari powerful kepada powerless. Secara lebih detail, proses pemberdayaan dapat diketahui dari apa yang diidentifikasi oleh Fetterman and Wandersman (2005) sebagai prinsip-prinsip evaluasi dalam pemberdayaan, yaitu (a) improvement; (b) Community ownership; (c) Inclusion; (d) Democratic participation; (e) Social justice; (f) Community knowledge; (g) Evidence-Based strategies; (h) Capacity building; (i) Organizational learning; dan (j) Accountability. Dengan demikian, proses pemberdayaan masyarakat dalam perumusan kebijakan di tingkat desa, terutama proses perumusan anggaran pendapatan dan belanja desa (APBDes) dapat diketahui dari (a) adanya peningkatan pemahaman dan kemampuan masyarakat; (b) masyarakat merasa memiliki kebijakannya; (c) masyarakat merasa menjadi bagian dari proses perumusan; (d) masyarakat ikut menentukan proses kebijakan; (e) masyarakat merasa diperlakukan dengan adil; (f) masyarakat menjadi lebih memahami proses kebijakan; (g) masyarakat berfikir tentang fakta atau data; (h) masyarakat meningkat kapasitasnya dalam proses perumusan; (i) masyarakat dan pemerintahan desa ikut belajar dari proses tersebut; dan (j) hasil semua proses dapat dipertanggungjawabkan atau sesuai dengan norma-norma yang ada dalam masyarakat.

Street-level bureaucracy. Konsep ini dikemukakan oleh Lipsky (1980). Lipsky menjelaskan bahwa meskipun birokrasi pemerintah itu kompleks dan seringkali konflik kepentingan dan struktur, namun bagi masyarakat atau warga negara itu tidak begitu penting dan tidak begitu terasa. Yang paling dirasakan warganegara, terutama dalam kebijakan dan pelayanan publik, adalah unit pemerintah yang langsung berhubungan dengan mereka. Dalam hal ini, ternyata tidak semua unit-unit pemerintah langsung berhubungan dengan warga negara. Unit-unit pemerintah yang langsung berhubungan dengan warga negara tersebut disebut street-level bureaucracy. Konsep ini sangat relevan dengan konsep desa di hadapan warga masyarakat pedesaan. Mereka berhadapan dengan pemerintah Republik Indonesia ketika mereka berhadapan dengan pemerintahan desa. Oleh karena itulah, konsep street-level bureaucracy dapat diterjemahkan mejadi birokrasi ujung tombak. Citra Pemerintah dan persepsi masyarakat tentang Pemerintah ditentukan oleh apa dan bagaimana birokrasi ujung tombak tersebut. Oleh karena itu, desa sebagai ujung tombak pemerintah menjadi sangat penting.

Dari tiga konsep tersebut di atas, maka bagaimana pemberdayaan masyarakat dalam perumusan APBDes menunjuk pada penguatan pemerintahan dan masyarakat desa sehingga keterlibatan mereka dalam proses APBDes manjadi sebuah kebutuhan, bukan opsional terutama bagi masyarakatnya. Secara lebih terinci, keterlibatan tersebut melalui peningkatan pemahaman dan kemampuan; merasa memiliki; merasa menjadi bagian dari proses; ikut menentukan; merasa diperlakukan 
dengan adil; menjadi lebih memahami proses kebijakan; berfikir tentang data; meningkat kapasitasnya; ikut belajar; dan dapat dipertanggungjawabkan atau sesuai dengan norma-norma yang ada dalam masyarakat, sebagaimana dikemukakan Fetterman (2007) di atas. dua desa, yaitu Desa Kotayasa dan Desa Banjarsari Kulon, Kecamatan Sumbang, Kabupaten Banyumas. Adapun sasaran penelitian ini adalah Badan Permusyawaratan Desa, Pemerintah dan perangkat Desa, dan Masyarakat Desa pada umumnya.

\section{B. METODE PENELITIAN}

Lokasi Penelitian. Penelitian ini berlokasi di Kabupaten Banyumas, pada
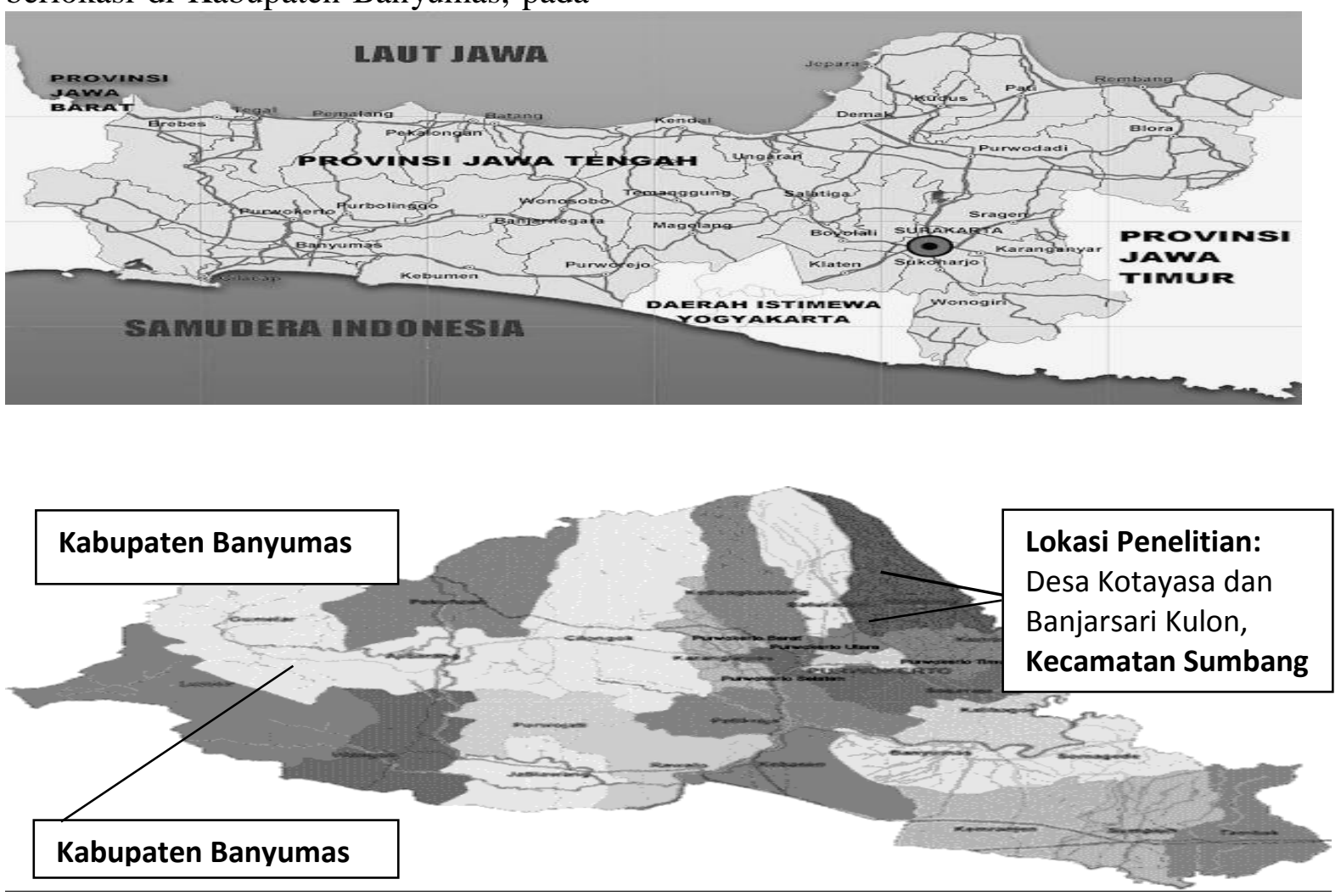

Pendekatan penelitian menggunakan embeded case study atau studi kasus terpancang. Pendekatan ini digunakan karena akan memberi peluang menggali kebutuhan, keinginan dan kemungkinan substansi pemberdayaan masyarakat desa dalam proses perumusan APBDes.

Teknik pengambilan sampling terdiri dari dua tahap. Pertama menggunakan tekhnik pusposive untuk mendapatkan informan yang berkaitan dengan perumusan APBDes. Sedangkan yang kedua menggunakan tekhnik aksidental random pada forum-forum pertemuan warga, baik tingkat Rukun Tetangga (RT) maupun Rukun Warga (RW) untuk mendapatkan responden yang mengisi daftar pertanyaan atau questionnaire.

Teknik Pengambilan Data. Metode pengumpulan data terutama 
adalah wawancara, focus-groupdiscussion (FGD), questionnaire dan analisis dokumen yang relevan. Teknik Analisis data dilakukan secara Interaktif, mulai dari pengumpulan data, kondensasi data, penampilan data, dan penarikan kesimpulan penelitian (Miles dan Hubermas, 2014) dan dikombinasi dengan teknik Delphi sederhana pada dua tingkatan. Hasil FGD dipakai untuk merumuskan pramodel pemberdayaan, sedangkan analisis berikutnya menggunakan tabulasi frekuensi untuk mengetahui perubahan skor dari perlakuan peningkatan pemahaman masyarakat tentang penganggaran (pre-test dan post-test)

\section{HASIL PENELITIAN DAN PEMBAHASAN}

\section{Gambaran Umum Lokasi Penelitian.}

Dua desa lokasi penelitian, Desa

Kotayasa dan Banjarsari Kulon termasuk wilayah Kecamatan Sumbang Kabupaten Banyumas. Kecamatan Sumbang merupakan satu kecamatan yang ada di tepat sebelah timur laut Kota Purwokerto, Kecamatan ini terdiri dari 19 desa. Dua desa lokasi penelitian terdiri dari desa terbesar dan desa yang relatif kecil. Tabel 4.1. berikut secara ringkas mendeskripsikan dua desa lokasi penelitian, Desa Kotayasa dan Banjarsari Kulon.

Tabel 1. Gambaran Ringkas Lokasi Penelitian

\begin{tabular}{|c|c|c|c|}
\hline \multirow[b]{2}{*}{ No } & \multirow[b]{2}{*}{ Uraian } & \multicolumn{2}{|c|}{ Lokasi Penelitian } \\
\hline & & Desa Kotayasa & $\begin{array}{c}\text { Desa Banjarsari } \\
\text { Kulon }\end{array}$ \\
\hline 1. & Luas Wilayah & $505,99 \mathrm{Ha}$ & $212,279 \mathrm{Ha}$ \\
\hline & a. Sawah & $184,65 \mathrm{Ha}$ & $99 \mathrm{Ha}$ \\
\hline & b. Tanah kering & $321,34 \mathrm{Ha}$ & $113,279 \mathrm{Ha}$ \\
\hline 2. & Jumlah Penduduk & 9.157 Jiwa (2.902KK) & 3.516 Jiwa $(1.035 \mathrm{KK})$ \\
\hline & a. Laki-laki & 4.651 Jiwa & 1.819 Jiwa \\
\hline & b. Perempuan & 4.506 Jiwa & 1.697 Jiwa \\
\hline 3. & Potensi Desa & $\begin{array}{ll}\text { a. } & \text { Pasar } \\
\text { b. } & \text { Air } \\
\text { c. } & \text { Pertanian } \\
\text { d. } & \text { Peternakan }\end{array}$ & $\begin{array}{l}\text { a. Peternakan } \\
\text { b. Perikanan Darat } \\
\text { c. Pertanian }\end{array}$ \\
\hline
\end{tabular}

4. Potensi Ekonomi
a. Penduduk Usia Produktif
4.450 Jiwa $(48,59 \%)$
(15-55Th)
1.061 orang
1.365 Jiwa $(38,82 \%)$
(18-56Th)
119 orang
b. Kegiatan Ekonomi

5. APBDes
a. Pendapatan
1) $\mathrm{PAD}$
2) Hasil Usaha Desa
3) Hasil Aset Desa
4) Hasil Swadaya
5) Pendapatan Transfer
2.098.384.487
338.145 .333
208.320 .000
125.825 .000
0
1.760 .239 .487
988.948 .595
28.688.032,00
a) Dana Desa
b) Bagian Pajak/Retribusi Kab.

Pemberdayaan Masyarakat melalui Reposisi Masyarakat dalam Proses

Perumusan Anggaran di Tingkat Desa 

c) $\mathrm{ADD}$
d) Bantuan Keuangan Provinsi
e) Bantuan Keuangan Kab
b. Belanja
c. Surplus (Defisit)

$\begin{array}{cr}707.602 .860 & 485.336 .590 \\ 35.000 .000 & 285.000 .000 \\ 0 & 500.000 .000 \\ 2.286 .580 .506 & 2.774 .760 .585 \\ (188.196 .019) & (171.176 .205)\end{array}$

Sumber: Sukarso et.al., 2017 dan 2018.

Dua desa ini mewakili desa dengan luas wilayah dan penduduk yang besar (Desa Kotayasa) dan desa dengan luas wilayah dan penduduk yang relatif kecil (Desa Banjarsari Kulon). Ada beberapa hal yang dapat disimpulkan dari dua desa ini secara komparatif: dua desa berbeda dalam luas wilayah dan penduduk, namun berbanding terbalik dengan besaran anggarannya, baik dari pendapatan keseluruhan maupun dari pendapatan asli desanya. Ternyata Desa Banjarsari Kulon justru relatif lebih besar anggarannya. Hal lain yang dapat dianggap persamaannya antara lain adalah swadaya masyarakat, kedua desa ternyata tidak ada dana swadaya masyarakat dalam masing-masing APBDes. Penjelasan tentang hal ini, selama ini swadaya masyarakat biasanya dalam bentuk material dan tenaga (gotong-royong atau kerja-bakti) bukan dalam bentuk rupiah.

Partisipasi Masyarakat Dalam Proses APBDes. Dalam proses perumusan APBDes selama ini keterlibatan masyarakat sangat terbatas pada Badan Permusyawaratan Desa sebagai wakil masyarakat yang terdiri dari lima orang dan para Kepala Dusun (Kadus) dua sampai tiga orang. Sedangkan pada Musyawarah Dusun (Musdus) umumnya terdiri dari Ketua RW dan RT. Dengan demikian, masyarakat umum tidak masuk secara langsung pada sistem perumusan APBDes. Komunikasi riil antar Stakeholders dalam perumusan APBDes yang teridentifikasi melalui wawancara dan FGD sebagai berikut.

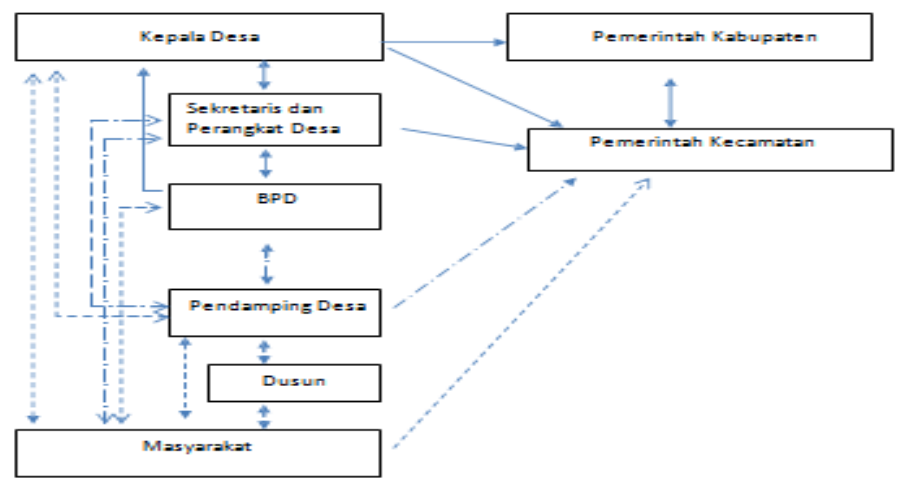

Gambar 1. Skema Komunikasi Antar Aktor dalam Perumusan APBDes.

Sumber : Sukarso, et.al., 2018.

Keterangan:

: Komunikasi lemah

: Komunikasi Sedang

: Komunikasi Kuat/Intens 
Dari skema di atas, nampak bahwa aktor utama dalam perumusan APBDes adalah Pemerintah Desa dan BPD serta Pemerintah Kabupaten (melalui Kecamatan), sementara posisi dan kontribusi masyarakat nampak seperti opsional saja.

Dari fenomena rendahnya partisipasi atau keterlibatan masyarakat tersebut, teridentifikasi adanya model alternatif untuk untuk meningkatkan partisipasi masyarakat atau model deliberatif. Model ini pada dasarnya me-reposisi masyarakat dari sekedar obyek dari kebijakan menjadi subyek dari kebijakan. Skema berikut menggambarkan reposisi masyarakat tersebut.

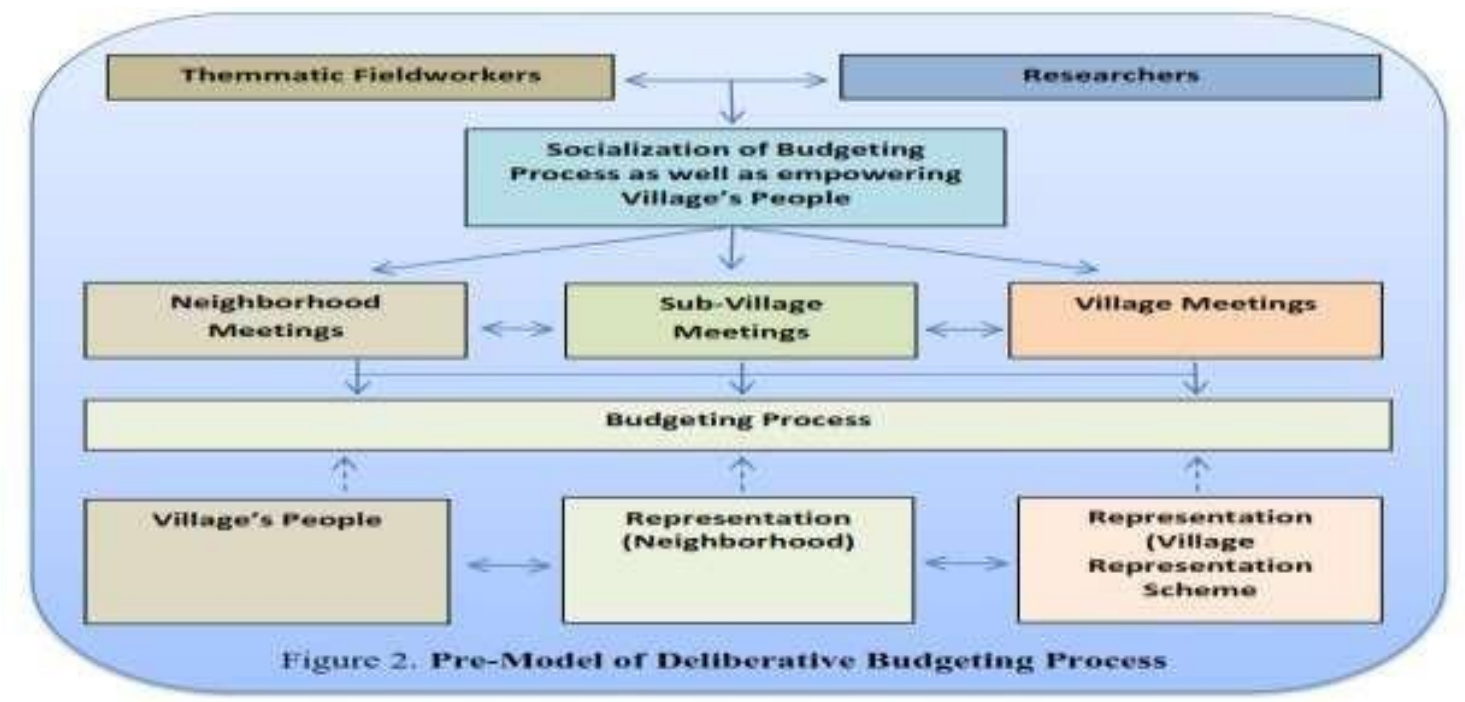

Sumber: Sukarso, et.al. 2018.

Perubahan posisi masyarakat tersebut sangat potensial mengingat jumlah penduduk desa relatif terbatas, sementara unit masyarakat terutama terdiri dari rumah tangga sehingga jumlah rumah tangga di desa relatif lebih terbatas lagi.

"Mereka berada dalam posisi yang ideal jika proses penyusunan anggaran desa melibatkan secara langsung, aktif atau pasif, dengan beberapa cara: (a) mengakui kebutuhan pribadi dan kebutuhan lainnya (komunitas atau "publik"); (b) tentukan tujuan dan sarana untuk mencapai tujuan tersebut; (c) ide-ide implementasi dan pembiayaan dalam segala bentuk selain dari yang disediakan oleh pemerintah; (d) pelaksanaan berbagai rencana yang telah ditetapkan ... sesuai dengan komitmen mereka; (e) pemantauan dan evaluasi berbagai program atau proyek yang dilakukan, hasil pemantauan dan evaluasi diakomodasi dalam diskusi program atau proyek berikutnya. Jika beberapa hal ini dapat melibatkan komunitas secara aktif atau pasif (dalam bentuk pemahaman), maka 
proses kebijakan deliberative dapat dicapai”. (ibid.)

Model deliberatif tersebut dapat direalisasikan menunjuk pada dua hal pokok: kemampuan pemerintahan dan masyarakat desa dan kebijakan pemerintah yang berkaitan dengan perumusan APBDes lebih dari sekedar akomodatif, namun memaksa (enforce) untuk keterlibatan masyarkat desa pada umumnya.
Kemampuan pemerintahan dan masyarakat desa dalam perumusan APBDes terdidentifikasi ada tiga aspek: administratif; hukum; dan sosiopsikologis. Tabel berikut ini perincian hasil pre-test dan post-test intervensi pada peningkatan pemahaman dan kemampuan serta kesadaran masyarakat dalam perumusan APBDes.

\section{Tabel 2. Hasil Perlakuan Peningkatan Pemahaman Tiga Aspek Dalam Perumusan} APBDes

\begin{tabular}{|c|c|c|c|c|}
\hline No. & Instrumen (skor 67 s/d 201) & $\begin{array}{l}\text { Pre- } \\
\text { test }\end{array}$ & $\begin{array}{c}\text { Post- } \\
\text { test }\end{array}$ & $\begin{array}{l}\text { Naik (+) } \\
\text { Turun (-) }\end{array}$ \\
\hline 1. & Aspek Hukum & & & \\
\hline a. & $\begin{array}{l}\text { Apakah Bapak/Ibu/Sdr mengetahui aturan-aturan tentang } \\
\text { pengelolaan Anggaran Desa? }\end{array}$ & $\begin{array}{c}87 \\
(1,29)\end{array}$ & $\begin{array}{c}138 \\
(2,05)\end{array}$ & $+58 \%$ \\
\hline b. & $\begin{array}{l}\text { Jika Bapak/Ibu/Sdr mengetahui, sebutkan apa saja aturan } \\
\text { yang ada? }\end{array}$ & $\begin{array}{c}77 \\
(1,14)\end{array}$ & $\begin{array}{c}146 \\
(2,77)\end{array}$ & $+89,6 \%$ \\
\hline c. & $\begin{array}{l}\text { Apakah Bapak/Ibu/Sdr mengetahui sangsi-sangsi terhadap } \\
\text { pelanggaran atau penyalahgunaan dalam Pengelolaan } \\
\text { APBDes? }\end{array}$ & $\begin{array}{c}92 \\
(1,37)\end{array}$ & $\begin{array}{l}163 \\
(2,43)\end{array}$ & $+77,1 \%$ \\
\hline d. & $\begin{array}{l}\text { Jika Bapak/Ibu/Sdr mengetahui, sebutkan sangsi-sangsi } \\
\text { tersebut? }\end{array}$ & $\begin{array}{c}86 \\
(1,28)\end{array}$ & $\begin{array}{l}156 \\
(2,32)\end{array}$ & $+81,3 \%$ \\
\hline e. & $\begin{array}{l}\text { Apakah Bapak/Ibu/Sdr mengetahui perbedaan sangsi } \\
\text { Pidana, Perdata dan Administratif? }\end{array}$ & $\begin{array}{c}94 \\
(1,4)\end{array}$ & $\begin{array}{c}158 \\
(2,35)\end{array}$ & $+68 \%$ \\
\hline 2. & Aspek Administratif & & & \\
\hline a. & $\begin{array}{l}\text { Dakah yang berwenang dan } \\
\text { engelolaan APBDes? }\end{array}$ & $\begin{array}{c}88 \\
(1,31)\end{array}$ & $\begin{array}{l}186 \\
(2,77)\end{array}$ & $+111,3 \%$ \\
\hline b. & $\begin{array}{l}\text { Apakah Bapak/Ibu/Sdr mengetahui jadwal perumusan } \\
\text { APBDes? }\end{array}$ & $\begin{array}{c}80 \\
(1,19)\end{array}$ & $\begin{array}{l}146 \\
(2,17)\end{array}$ & $+82,5 \%$ \\
\hline c. & $\begin{array}{l}\text { Apakah Bapak/Ibu/Sdr mengetahui tentang jenis-jenis dana } \\
\text { yang ada di APBDes? }\end{array}$ & $\begin{array}{c}82 \\
(1,22)\end{array}$ & $\begin{array}{l}180 \\
(2,68)\end{array}$ & $+119,5 \%$ \\
\hline d. & $\begin{array}{l}\text { Apakah Bapak/Ibu/Sdr mengetahui peruntukan atau } \\
\text { pengalokasian jenis-jenis dana tersebut? }\end{array}$ & $\begin{array}{c}82 \\
(1,22)\end{array}$ & $\begin{array}{l}177 \\
(2,64)\end{array}$ & $+115,8 \%$ \\
\hline e. & $\begin{array}{l}\text { Apakah Bapak/Ibu/Sdr mengetahui besaran masing-masing } \\
\text { jenis dana yang ada di APBDes? }\end{array}$ & $\begin{array}{c}79 \\
(1,79)\end{array}$ & $\begin{array}{l}156 \\
(2,32)\end{array}$ & $+97,4 \%$ \\
\hline f. & $\begin{array}{l}\text { Apakah Bapak/Ibu/Sdr mengetahui saldo akhir menjadi } \\
\text { saldo awal di tahun berikutnya? }\end{array}$ & $\begin{array}{c}80 \\
(1,19)\end{array}$ & $\begin{array}{l}140 \\
(2,08)\end{array}$ & $+75 \%$ \\
\hline 3. & Aspek Sosio-psikologis & & & \\
\hline a. & $\begin{array}{l}\text { Apakah Bapak/Ibu/Sdr memahami proses perumusan } \\
\text { APBDes? }\end{array}$ & $\begin{array}{c}84 \\
(1,25)\end{array}$ & $\begin{array}{c}152 \\
(2,26)\end{array}$ & $+80,9 \%$ \\
\hline b. & $\begin{array}{l}\text { Apakah Bapak/Ibu/Sdr ingin berpartisipasi dalam proses } \\
\text { perumusan APBDes tahun depan? }\end{array}$ & $\begin{array}{c}142 \\
(2,11)\end{array}$ & $\begin{array}{l}189 \\
(2,82)\end{array}$ & $+33 \%$ \\
\hline
\end{tabular}

Pemberdayaan Masyarakat melalui Reposisi Masyarakat dalam Proses

Perumusan Anggaran di Tingkat Desa 
c. Apakah Bapak/Ibu/Sdr memahami pelaksanaan APBDes?

$\begin{array}{ccc}84 & 109 & +29,7 \% \\ (1,25) & (1,62) & \\ 130 & 188 & +44,6 \% \\ (1,94) & (2,80) & \\ 77 & 146 & +89,6 \% \\ (1,14) & (2,17) & \\ 143 & 192 & +34,2 \% \\ (2,13) & (2,86) & \\ 77 & 135 & +75,3 \% \\ (1,14) & (2,01) & \\ 140 & 193 & +37,8 \% \\ (2,08) & (2,88) & \\ 93 & 156 & +67,7 \% \\ (1,38) & (2,32) & \\ 81 & 136 & +67,9 \% \\ (1,20) & (2,02) & \end{array}$

Keterangan: Skala instrumen $1 \mathrm{~s} / \mathrm{d} 5 ; \mathrm{n}=67$ (cluster random)

Sumber: Data primer 2018 diolah, Sukarso, et.al. 2018.

Penelitian ini membuktikan bahwa masyarakat apabila diberikan perlakuan peningkatan pemahaman pada tiga aspek pemberdayaan masyarakat, yaitu aspek hukum, aspek administratif, dan aspek sosio-psikologis, ternyata terjadi peningkatan yang cukup signifikan. Peningkatan terendah $29,7 \%$ sedangkan yang tertinggi $119,5 \%$ dan rata-rata dari ketiga aspek tersebut meningkat $73,15 \%$. Perincian peningkatan tersebut sebagai berikut, peningkatan pemahaman terhadap pada hukum adalah 74,8\%; peningkatan pemahaman pada aspek administratif adalah 100,25\%; dan peningkatan pada aspek sosio-psikologis adalah 56,07\% .

Dari hasil ini, dapat dikatakan bahwa kemungkinan atau prospek untuk memberdayakan masyarakat dalam proses perumusan APBDes sangat tinggi, dengan kata lain, pemberdayaan masyarakat dalam proses perumusan kebijakan APBDes melalui peningkatan pemahaman mereka dalam tiga aspek tersebut sangat memungkinkan. Dari hasil pre-test dan post-test juga dapat disimpulkan bahwa pemberdayaan masyarakat yang relatif paling mudah adalah peningkatan pemahaman masyarakat dalam aspek administratif (rata-rata meningkat 100,25\%), sedangkan yang paling sulit adalah peningkatan aspek sosio-psikologis (meningkat 56,07\%).

Pemberdayaan Masyarakat Dalam Proses APBDes. Dari hasil wawancara dan diskusi terfokus, kelemahan yang paling dirasakan masyarakat pada umumnya dalam proses penganggaran dapat dibedakan pada tiga aspek: hukum, administratif, dan sosiopsikologis. Aspek hukum berkaitan dengan pemahaman tentang aturan-aturan yang ada dalam proses penganggaran, meliputi hak dan kewajiban masyarakat, termasuk sangsi-sangsi terhadap pelanggaran yang terjadi. Aspek administratif berkaitan dengan prosedur dan persyaratan administratif dalam proses penganggaran. Sedangkan aspek sosio-psikologis berkaitan dengan kesadaran dan pemahaman masyarakat mengenai hak dan kewajiban sebagai 
warga masyarakat berhadapan dengan hak dan kewajiban pemerintah untuk masyarakat. Kajian partisipasi masyarakat dalam penganggaran yang cenderung pada faktor mekanisme dan lingkungan politik masyarakat yang dianggap berpengaruh (Liao and Zhang, 2011; Mbambo, et al., 2016; ), atau faktor infrastructure (Gordon, et.al., 2016; Lim dan Oh, 2016)) dan keterlibatan penduduk lokal sebagai manajer (Chirenje, et.al., 2012). Kajian ini membuktikan tingkat keberdayaan masyarakat merupakan faktor kunci untuk merubah posisi masyarakat dari sekedar obyek kebijakan menjadi subyek kebijakan.

Dari hasil angket mengenai tiga aspek tersebut, melalui instrumen pre-test dan post-test terhadap responden secara acak dengan perlakuan diskusi dan sosialisasi, ternyata ada perubahan yang signifikan. Pada aspek hukum, sebelum diskusi mereka sebagian besar tidak tahu dan tidak ingin tahu tentang aturan-aturan yang ada dalam penganggaran. Setelah diskusi mereka menjadi agak tahu aturanaturan yang ada dan ingin tahu lebih banyak tentang aturan-aturan tersebut. Pada aspek Administratif, sebelum diskusi dan sosialisasi mereka sebagian besar tidak tahu apa dan bagaimana merumuskan APBDes. Namun setelah diskusi dan sosialisasi mereka menjadi agak tahu dan ingin tahu lebih banyak tentang teknis administratif dalam perumusan APBDes. Demikian pula dalam aspek sosio-psikologis, sebelum diskusi dan sosialisasi mereka sebagian besar cenderung apatis dan takut ikutikutan dalam proses penganggaran. Namun setelah diskusi dan sosialisasi, mereka menjadi lebih peduli dan relatif lebih berani untuk mengemukakan pendapat dan berkeinginan terliabat lebih jauh dalam proses penganggaran.

Dari hasil penelitian tersebut, ternyata potensi masyarakat untuk berubah dari apatis menjadi peduli dan dari takut menjadi berani cukup besar, padahal perlakuan diskusi dan sosialisasi dilakukan sangat terbatas baik dari segi waktu maupun dari segi substansi. Oleh karena itu, kemungkinan meningkatkan keterlibatan masyarakat dalam proses penganggaran lebih dari hanya sekedar partisipasi ternyata cukup besar. Masyarakat tidak terlibat dalam perumusan APBDes di satu sisi lebih dikarenakan pemahaman mereka pada tiga aspek: hukum, teknis administratif dan sosio-psikologis dalam penganggaran, di sisi lain juga karena kebijakan penganggaran pemerintah yang ada selama ini terlalu elitis karena tidak mesyaratkan keterlibatan masyarakat secara langsung. Oleh karena itu, upaya mereposisi masyarakat desa dalam penganggaran dapat dilakukan secara simultan dari dua sisi: sisi masyarakat dan sisi pemerintah. Dari sisi pemerintah menunjuk pada perlunya kebijakan penganggaran yang tidak lagi elitis, sementara dari sisi masyarakat perlu adanya pemberdayaan masyarakat setidaknya dalam tiga aspek: hukum, teknis administratif, dan sosio-psikologis. Dengan demikian, Potensi masyarakat menjadi subyek dari penganggaran perlu digali dengan pemberdayaan masyarakat.

\section{PENUTUP \\ Kesimpulan}

Berdasarkan hasil penelitian dan diskusi tersebut, dapat disimpulkan bahwa ada potensi yang besar untuk meningkatkan keberdayaan masyarakat desa dalam perumusan APBDes lebih dari hanya sekedar partisipasi volunter, 
akan tetapi mereposisi masyarakat desa menjadi bagian dari subyek perumusan APBDes. Model pemberdayaan masyarakat dalam perumusan APBdes tersebut terfokus pada peningkatan pemahaman dan kesadaran masyarakat desa pada tiga aspek: aspek hukum dalam penganggaran, aspek teknis-administratif dalam penganggaran, dan aspek sosiopsikologis masyarakat ketika berhadapan dengan pemerintah. Peningkatan pemahaman administratif berupa peningkatan pengetahuan masyarakat tentang berbagai prosedur administratif yang ada dalam proses perumusan APBDes. Peningkatan pemahaman hukum berupa peningkatan pengetahuan masyarakat tentang berbagai aturan yang ada dalam proses perumusan APBDes. Sedangkan peningkatan kesadaran sosiopsikologis berupa kesadaran akan hak dan kewajiban masyarakat desa vis-a-vis dengan hak dan kewajiban pemerintah dari tingkat desa sampai nasional.

Secara simultan, upaya pemberdayaan masyarakat tersebut harus diikuti dengan kebijakan penganggaran yang tidak elitis dari pemerintah, terutama tentang peningkatan hak dan kewajiban masyarakat desa dalam perumusan APBDes. Kebijakan ini dapat berupa Peraturan Pemerintah, Peraturan Menteri Keuangan, Peraturan Menteri Dalam Negeri, sampai pada Peraturan Daerah Provinsi dan Kabupaten/Kota.

\section{DAFTAR PUSTAKA}

Arnstein, Sherry R., (1969), A Ladder of Citizen Participation, on Journal of the American Planning Association, Vol. 35, No. 4, July 1969, pp. 216-224.

Chirenje, Leonard I., Richard A. Giliba and Emmanuel B. Musamba, (2013), Local communities' participation in decision-making processes through planning and budgeting in African countries, on Chinese Journal of Population Resources and Environment, Vol. 11 No. 1. Doi: doi.org/10.1080/10042857. 2013.777198

Fetterman, David M. and Abraham Wandersman, (2005), Empowerment Evaluation Principles in Practice, The Guilford Press, New York.

Gordon, Victoria, Jeffery L. Osgood Jr., and Daniel Boden, (2017), The Role of Citizen Participation and the Use of Social Media Platforms in the Participatory Budgeting Process, on International Journal of Public Administration, Vol. 40 No. 1. Doi: doi.org/10.1080/ $\underline{01900692.2015 .1072215}$

Jacobs, Keith, (2001), Devolved Budget Making within Local Authority Housing Departments: Staff Perceptions of Power and Control, on Local Government Studies, Vol.27, No.2 (Summer 2001), pp.93-110. 
Lewis, Carol W., How to Read a Local Budget and Assess Government Performance, on Anwar Shah (Ed.), (2007), Local Budgeting (Public Sector Governance And Accountability Series), The International Bank for Reconstruction and Development/The World Bank.

Liao, Yuguo and Yahong Zhang, (2012), Citizen Participation in

Local Budgeting: Mechanisms, Political Support, and City Manager's Moderating Role, on International Review of Public Administration, Vol. 17 No. 2. Doi: doi.org/10.1080/12294659. 2012.10805226.

Lim, Seunghoo and Youngmin Oh, (2016), Online Versus Offline Participation: Has the Democratic Potential of the Internet Been Realized? Analysis of a Participatory Budgeting System in Korea, on Public Performance \& Management Review, Vol. 39 No. 3. pp. 676700. Doi: doi.org/10.1080/ $\underline{15309576.2016 .1146553}$

Lipsky, Michael, (1980), Street-Level Bureaucracy: Dilemmas of the Individual in Public Services, the Russell Sage Foundation, New York City.

Lorsuwannarat, Tippawan, (2017), Public Participation in Budgetin g: The New Path of Budget Reform in Thailand, on International Journal of Public Administration, Vol. 40,
No. 5, (p. 385-400). Doi: doi.org/10.1080/01900692.2015. 1126730.

Mbambo, William Bongile, D.R. Thakhathi and Akeem Adewale Oyelana, (2016), The Importance Community Participation in the Budgetary Process in the Eastern Cape of South Africa, on Journal of Social Sciences, Vol. 49 No. 3-2. https://doi.org/10.1080/0971892 3.2016.11893623.

Miles, Matthew B., A. Michael Huberman and Johnny Saldana, (2014), Qualitative Data Analysis: A Methods Sourcebook, 3rd edt., Sage, Los Angeles.

Sukarso, Swastha Dharma, dan Niken Paramarti Dasuki (2017), Community Participation on Village Budgeting In Local Government of Indonesia: A Case Study in Banyumas District, Central Java, Proceeding International Seminar: Reconstructing Public Administration Reform To Build World Class Government, Lembaga Administrasi Negara, Jakarta, 21-22 Agustus 2017 (390-399).

Sukarso, Swastha Dharma, Niken Paramarti Dasuki, (2018), Model Pemberdayaan Masyarakat Dalam Pembangunan: Studi Kasus Dalam Perumusan APBDes Di Desa Kotayasa dan Banjarsari Kulon, Kecamatan 

${ }^{3}$ Prodi Sosiologi Universitas Jendral Sudirman

\begin{tabular}{|c|c|}
\hline $\begin{array}{lr}\text { Sumbang, } & \text { Kabupaten } \\
\text { Banyumas, dalam Edi Santoso, } \\
\text { ed. (2018), } & \text { Pemberdayaan } \\
\text { Masyarakat: } & \text { Perspektif }\end{array}$ & $\begin{array}{l}\text { Komunikasi, } \\
\text { Budaya, dan Politik, Yanisasi, } \\
\text { Literasi Bangsa dan Fisip } \\
\text { Unsoed. }\end{array}$ \\
\hline
\end{tabular}

